\title{
Low level STK15 amplification in histologically benign urothelium of patients with bladder cancer adversely predicts patient outcome following cystectomy
}

\author{
STEFAN DENZINGER ${ }^{1}$, ROBERT STOEHR ${ }^{1}$, STEPHAN SCHWARZ ${ }^{2}$, \\ NICOLE EICHENSEHER ${ }^{2}$, GERO BROCKHOFF ${ }^{2}$, ELLEN C. OBERMANN ${ }^{2}$, RUTH KNUECHEL $^{3}$, \\ HAGEN BLASZYK $^{4}$, ARNDT HARTMANN ${ }^{2}$ and PETER J. WILD ${ }^{5}$
}

\begin{abstract}
${ }^{1}$ Department of Urology and ${ }^{2}$ Institute of Pathology, University of Regensburg, Franz-Josef-Strauss-Allee 11, D-93053 Regensburg; ${ }^{3}$ Institute of Pathology, University of Aachen, Pauwelsstrasse 30, D-52074 Aachen, Germany;

${ }^{4}$ Department of Pathology, University of Vermont College of Medicine, 111 Colchester Avenue, Burlington, 05401 VT, USA; 5 Institute of Clinical Pathology, University Hospital Zurich,

Schmelzbergstrasse 12, CH-8091 Zurich, Switzerland
\end{abstract}

Received March 29, 2007; Accepted May 11, 2007

\begin{abstract}
The aim of this study was to investigate STK15 amplification in histologically benign urothelium and invasive tumor tissue of urothelial bladder cancer patients in relation to clinicopathologic and molecular characteristics, and to analyze a hypothesized association between the STK15 single nucleotide polymorphism at site T91A (Phe31Ile) and STK15 gene amplification. A tissue microarray (TMA) was constructed and contained formalin-fixed paraffin-embedded tumor tissue and matching histologically benign urothelium of 44 patients who underwent cystectomy for invasive urothelial carcinoma. Expression of TP53, CK20 and MIB1 was evaluated by immunohistochemistry. UroVysion and STK15 fluorescence in situ hybridization (FISH) analysis was performed for sensitive detection of polysomy, relative p16 deletion and STK15 amplification, respectively. Genotypes of STK15 at the T91A (Phe31Ile) site were analyzed by PCR-RFLP assay. Low level STK15 amplification was found in 2 of 36 analyzable histologically benign urothelium specimens $(5.6 \%)$ and in $64 \%$ (28/44) of urothelial bladder cancers, whereas $36 \%(16 / 44)$ of cancer lesions showed high level of STK15 amplification. In histologically benign urothelium of bladder cancer patients, low level STK15 amplification was associated with shorter recurrence-free and tumor-specific survival. There was no correlation between allelic variants and high/low level of STK15 gene amplification. Applying STK15 FISH to benign urothelium of
\end{abstract}

Correspondence to: Dr Peter J. Wild, Institute of Clinical Pathology, University Hospital Zurich, Schmelzbergstrasse 12, CH-8091 Zurich, Switzerland

E-mail: peter.wild@usz.ch.

Key words: bladder cancer, histologically benign urothelium, fluorescence in situ hybridization, STK15, SNP analysis bladder cancer patients may help to identify patients at increased risk for adverse clinical outcome. A large randomized prospective study comparing early versus delayed cystectomy in patients with pT1 bladder cancer is currently conducted to validate our findings.

\section{Introduction}

Aneuploidy and genomic instability are common features of tumor cells $(1,2)$. Aneuploidy is often associated with aggressive tumor phenotypes, and it is thus possible that genes regulating chromosome segregation are involved in tumor progression (3). The recently characterized STK15 gene (Aurora A) on chromosome 20q13 (4) encodes for a centrosome-associated serine/threonine kinase, and is a member of the Aurora/IPL kinase family which has been implicated in the regulation of centrosome duplication. The Aurora-A kinase is specifically associated with the centrosome of interphase cells as well as with the spindle apparatus during mitosis (4). Gene amplification and over-expression of STK15 has been reported frequently in human tumors [e.g. breast and colon cancer $(5,6)]$ and in association with high degrees of genomic instability, suggesting that the STK15 protein may represent a critical regulatory component of chromosomal segregation causing aneuploidy and malignant transformation. Amplification and overexpression of STK15 was indicative of tumor aggressiveness and poor patient outcome (7-9). STK15 amplification in histologically benign urothelium of bladder cancer patients has not yet been investigated. A functional polymorphism in STK15 is caused by single nucleotide substitution at gene sequence position $91(\mathrm{~T} \rightarrow \mathrm{A})$ and leads to replacement of Phe by Ile at amino acid sequence position 31 (10). In colorectal cancer, specific amplification of the $91 \mathrm{~A}$-allele was associated with a higher degree of chromosomal imbalances in tumors from individuals homozygous for the 91A genotype. Meta-analysis of the STK15 Phe31Ile polymorphism demonstrated that the 
91A-allele is a low penetrance cancer susceptibility allele affecting multiple cancer types (11). To our knowledge, there is no study analyzing the role of the STK15 Phe31Ile polymorphism in urothelial bladder cancer. The aim of this study was: i) to investigate STK15 amplification in histologically benign urothelium and invasive tumor tissue of bladder cancer patients following cystectomy relative to clinicopathologic and molecular characteristics; and ii) to analyze an hypothesized association between STK15 genotypes at the polymorphism T91A (Phe31Ile) and STK15 amplification in our patient cohort as it has been previously described in colorectal cancer.

\section{Materials and methods}

Cystectomy tissue microarray (TMA). A TMA was constructed as described previously (12) and contained formalin-fixed paraffin-embedded tumor tissue and histologically benign urothelium of 44 patients with invasive urothelial bladder cancer. All specimens were selected from a retrospective single center cystectomy study, obtained between 1993 and 2003 from the Institute of Pathology, University of Regensburg, Germany (UICC stage I-IV). In cases of multiple synchronous bladder tumors, the invasive cancer lesion with the worst histological stage and grade was chosen. Two surgical pathologists (A.H. and P.J.W.) evaluated H\&E-stained slides of all cases. Tumor stage and grade were assigned according to International Union Against Cancer (UICC) and World Health Organization (WHO) criteria (13). Papillary tumor growth pattern was defined by the presence of a papillary tumor component ( $\geq 20 \%$ with a histologic grade identical to the invasive tumor). Tumors with both a papillary and a solid component were defined as mixed. All other tumors were considered to have a solid growth pattern. In case of multi-focal synchronous bladder cancer, growth patterns of each invasive lesion were evaluated separately. Median clinical follow-up period was 40 months (range 6-121 months). Time to recurrence and time to tumor-related death were selected as end points. Clinicopathologic data of the cystectomy TMA are summarized in Table I.

Immunohistochemistry (IHC). Immunohistochemical studies for the expression of TP53, CK20 and MIB1 utilized an avidin-biotin peroxidase method with a 3,3'-diaminobenzidine (DAB) chromatogen. After antigen retrieval (microwave oven for $30 \mathrm{~min}$ at $250 \mathrm{~W}$ ), immunohistochemistry was carried out in a NEXES immunostainer (Ventana, Tucson, AZ) following manufacturer's instructions. The following primary antibodies were used: anti-TP53 [mouse monoclonal $\mathrm{IgG}$, clone Bp53-12 (sc-263), Santa Cruz Biotechnology, Inc., Santa Cruz, CA; dilution 1:1,000], anti-CK20 [mouse monoclonal IgG2a, clone IT-Ks20.8 (61026), Progen Biotechnik GmbH, Heidelberg, Germany; dilution 1:10], and anti-Ki-67 [mouse monoclonal IgG1, clone MIB-1 (M7240), Dako, Glostrup, Denmark; dilution 1:50]. One surgical pathologist (A.H.) performed the evaluation of the slides without knowledge of clinical data. Causes of noninterpretable results included lack of tumor tissue and presence of necrosis or crush artifact. Cut-off levels for
Table I. Clinicopathologic characteristics.

\begin{tabular}{|c|c|c|}
\hline Variable & $\mathrm{n}$ analyzable & $\%$ \\
\hline \multicolumn{3}{|l|}{ Total $(n=44)$} \\
\hline \multicolumn{3}{|c|}{$\begin{array}{l}\text { Age when cystectomy } \\
\text { was performed }\end{array}$} \\
\hline$\leq 70$ years & 24 & 54.5 \\
\hline$>70$ years & 20 & 45.5 \\
\hline \multicolumn{3}{|l|}{ Gender } \\
\hline Female & 14 & 31.8 \\
\hline Male & 30 & 68.2 \\
\hline \multicolumn{3}{|l|}{ Tumor stage } \\
\hline pT1 & 12 & 27.3 \\
\hline $\mathrm{pT} 2 \mathrm{a} / \mathrm{b}$ & 13 & 29.5 \\
\hline $\mathrm{pT} 3 \mathrm{a} / \mathrm{b}$ & 14 & 31.8 \\
\hline $\mathrm{pT} 4 \mathrm{a} / \mathrm{b}$ & 5 & 11.4 \\
\hline \multicolumn{3}{|l|}{ Histologic grade } \\
\hline Low grade & 3 & 6.8 \\
\hline High grade & 41 & 93.2 \\
\hline \multicolumn{3}{|l|}{ Lymph node status } \\
\hline pNO & 34 & 77.3 \\
\hline $\mathrm{pN} 1$ & 10 & 22.7 \\
\hline \multicolumn{3}{|c|}{ Residual tumor status } \\
\hline R0 & 36 & 81.8 \\
\hline $\mathrm{R} 1$ & 8 & 18.2 \\
\hline \multicolumn{3}{|c|}{ Adjacent carcinoma in situ } \\
\hline No pTis & 18 & 40.9 \\
\hline pTis & 26 & 59.1 \\
\hline \multicolumn{3}{|l|}{ Multifocality } \\
\hline Unifocal tumor & 12 & 27.3 \\
\hline Multifocal tumor & 32 & 72.7 \\
\hline \multicolumn{3}{|l|}{ Growth pattern } \\
\hline Papillary & 8 & 18.2 \\
\hline Solid & 22 & 50.0 \\
\hline Mixed & 14 & 31.8 \\
\hline
\end{tabular}

TP53 and MIB1 were defined at 10\%. Cytokeratin 20 (CK20) is a sensitive marker of urothelial differentiation. CK20 staining was defined as normal (superficial staining pattern) or abnormal (negative or $\geq 10 \%$ stained) according to Harnden et al (14).

STK15 gene amplification detected by FISH. STK15 FISH analysis of the cystectomy TMA was performed according to Sen et al (8). BAC-clones for probe preparation were purchased from RZPD (Deutsches Ressourcenzentrum fuer Genomforschung GmbH, Berlin). After cultivation, harvest and DNA isolation Nick translation was performed, incorporating commercially available (Abbott Laboratories, Abbott Park, IL) Spectrum Orange dye into the gene probe. The spectrum green labeled centromeric probe (chromosome 20) was purchased from Abbott Laboratories. FISH was performed as described below. 
UroVysion FISH. Additionally, UroVysion fluorescent probe kits (Abbott Laboratories) were used according to manufacturer's instructions to assess aberrations of chromosomes 3, 7 and 17 by centromeric probes and to detect deletions of p16 on locus 9p21 of specimens on the cystectomy TMA. In brief, $6 \mu \mathrm{m}$ dewaxed tissue sections of the TMA were treated with proteinase $\mathrm{K}$ for $15 \mathrm{~min}$ at $37^{\circ} \mathrm{C}$, followed by washing and ethanol dehydration $(75,85$ and $100 \%)$. Slides were dried at $37^{\circ} \mathrm{C}$ and then heat denatured $\left(73^{\circ} \mathrm{C}\right.$ for $\left.15 \mathrm{~min}\right)$. For hybridization, $14 \mu 1$ of the original kit were used per slide. Slides were covered by a cover glass and fixogumm and heated at $96^{\circ} \mathrm{C}$ for $9 \mathrm{~min}$. This procedure was followed by an incubation at $37^{\circ} \mathrm{C}$ for at least $12 \mathrm{~h}$. After resolving the cover glass using $2 \mathrm{x} \mathrm{SSC} / 0.3 \% \mathrm{NP} 40$ solution, DAPI nuclear counter staining was carried out. For each case 50 nuclei were selected for scoring according to morphological criteria using DAPI staining. Only non-overlapping intact nuclei of urothelial cells were scored.

Scoring of FISH signals. All hybridizations were evaluated independently by two investigators (N.E. and P.J.W.) and the mean of both counts was used. Low level STK15 amplification was defined if the ratio STK15/chromosome 20 was at least $>2.0$. A sample was considered carrying a highlevel STK15 amplification if the ratio STK15/chromosome 20 was $>4.0$.

UroVysion FISH simultaneously analyzed each cell for centromer signals of chromosomes 3, 7 and 17, and for the p16 locus on 9p21. A cell was considered aberrant if at least one of three centromeric signals was amplified ( $>2$ signals per cell), or if 9p21 was deleted. Polyploid cells (4 signals of all the three probes) were regarded normal (euploid). A relative deletion of the 16 locus was recognized if the signal number of 9 p21 was $>1$ unit lower than the mean value of the centromeric signals. Frequencies of polysomy and deletions of 9p21 in non-tumor associated urothelium (data not shown) defined a cut-off value of three times standard deviation. A case was considered aberrant if $>9$ cells out of 50 showed polysomy ( $>18 \%$ of the cells). A sample was considered carrying a deletion of $\mathrm{p} 16$ if $>7$ out of 50 cells $(>14 \%$ of the cells) showed a relative deletion of locus 9 p21.

SNP analysis. Genomic DNA of patients on the TMA was isolated from $5 \mu \mathrm{m}$ tissue paraffin sections. For molecular analysis, DNA was extracted using the High Pure PCR Template Preparation Kit (Roche, Mannheim, Germany) according to the manufacturer's specifications. Genotypes of STK15 at the T91A (Phe31Ile) site were analyzed by PCR-RFLP assay. The primers for PCR were: sense 5'-CTC AATATATTCATCTTTTGC-3', antisense 5'-AGGACAC AAGACCCGCTG-3'. Amplification was accomplished with a $25 \mu 1$ reaction mixture containing $100 \mathrm{ng}$ DNA, $0.2 \mathrm{mmol} / \mathrm{l}$ dNTPs, $0.3 \mu \mathrm{mol} / 1$ primers, $1.5 \mathrm{mmol} / 1 \mathrm{MgCl}_{2}$ and $0.5 \mathrm{U}$ GoTaq ${ }^{\circledR}$ DNA polymerase (Promega GmbH, Mannheim, Germany). The reaction mixture was subjected to $3 \mathrm{~min}$ of denaturing at $95^{\circ} \mathrm{C}$ and 35 cycles of $95^{\circ} \mathrm{C}$ for $1 \mathrm{~min}$, specific annealing temperature of $50^{\circ} \mathrm{C}$ for $1 \mathrm{~min}$ and $72^{\circ} \mathrm{C}$ for $1 \mathrm{~min}$, followed by a final extension step at $72^{\circ} \mathrm{C}$ for $10 \mathrm{~min}$. PCR conditions were optimized by gradient PCR and were carried out in a MJ Research Thermocycler (PTC100). The 170 bp
PCR products were then digested with ApoI (New England BioLabs, Beverly, MA), separated on a $2.5 \%$ agarose gel and visualized under UV light by using $0.05 \%$ ethidium bromide. The Phe allele had no ApoI restriction site and resulted in one band (170 bp), whereas the Ile allele had one ApoI restriction site and thus produced two bands $(109+61 \mathrm{bp})$. Specificity of genotyping using PCR-RFLP assay was confirmed by DNA sequencing of urothelial cell lines with $100 \%$ reproducibility (data not shown).

Statistical analysis. Statistical analyses were completed using SPSS version 10.0 (SPSS, Chicago, IL). P-values $<0.05$ were considered significant. Contingency table analysis and two-sided Fisher's exact tests were used to study the statistical association between clinicopathologic, molecular and immunohistochemical data. Survival curves comparing patients with or without any of the factors were calculated using the Kaplan-Meier method, with significance evaluated by two-sided log-rank statistics. For recurrence-free survival, patients were censored at time of their last tumor-free clinical follow-up appointment. For tumor-specific survival, patients were censored at the time of their last clinical follow-up appointment or at their date of death not related to the tumor. A multivariable Cox regression model concerning recurrence-free survival was adjusted, testing the independent prognostic relevance of STK15 low level amplification in matching histologically benign urothelium of patients with invasive urothelial bladder cancer receiving cystectomy.

\section{Results}

Immunohistochemistry. Results of immunohistochemical analyses in tumor tissue and matching histologically benign urothelium are summarized in Table II. A pical expression of the dedifferentiation marker CK20 was seen in $76.5 \%$ $(26 / 34)$ of informative cases; whereas, $23.5 \%$ of histologically benign samples (8/34) and $100 \%$ (44/44) of invasive carcinomas revealed abnormal CK20 staining pattern.

Invasive tumors $(48.8 \%, 21 / 43)$ and $13.2 \%(5 / 38)$ of histologically benign urothelium specimens showed positive TP53 immunoreactivity in at least $10 \%$ of nuclei. Representative CK20 and TP53 immunostaining patterns in urothelial carcinomas and matching histologically benign urothelium are shown in Fig. 1. Interestingly, 29.7\% (11/37) of histologically benign samples and $100 \%(44 / 44)$ of carcinomas demonstrated a Ki-67 proliferation fraction of at least $10 \%$.

UroVysion FISH. A sample was considered aneuploid, if $>18 \%$ of the cells displayed polysomy of one or more chromosomes (see Materials and methods). Invasive urothelial carcinomas $(90.9 \%, 40 / 44)$ and $2.8 \%(1 / 36)$ of histologically benign samples showed polysomy of at least one chromosome. A relative deletion of $9 \mathrm{p} 21$ was found in 3 of $34(8.8 \%)$ histologically benign urothelium specimens and in $45.5 \%(20 / 44)$ of invasive tumors, respectively.

STK15 FISH. Investigation of STK15 amplification in a series of urothelial bladder cancers and histologically benign urothelium using TMA technology was informative in $100 \%$ (44/44) and 82\% (36/44) of cases, respectively. Fig. 2 shows 
Table II. Results of molecular and immunohistochemical analyses in tumor tissue and matching normal urothelium.

\begin{tabular}{|c|c|c|c|c|}
\hline \multirow[b]{2}{*}{ Variable } & \multicolumn{2}{|c|}{ Normal urothelium } & \multicolumn{2}{|c|}{ Urothelial cancer } \\
\hline & $\mathrm{n}$ analyzable & $\%$ & $\mathrm{n}$ analyzable & $\%$ \\
\hline \multicolumn{5}{|l|}{ Immunohistochemistry (IHC) } \\
\hline \multicolumn{5}{|l|}{ Ki-67 labeling index } \\
\hline$<10 \%$ & 26 & 70.3 & 0 & 0 \\
\hline$\geq 10 \%$ & 11 & 29.7 & 44 & 100 \\
\hline \multicolumn{5}{|l|}{ p53 IHC } \\
\hline$<10 \%$ & 33 & 86.8 & 22 & 51.2 \\
\hline$\geq 10 \%$ & 5 & 13.2 & 21 & 48.8 \\
\hline \multicolumn{5}{|l|}{ CK20 IHC } \\
\hline Superficial staining pattern & 26 & 76.5 & 0 & 0 \\
\hline Negative or $\geq 10 \%$ & 8 & 23.5 & 44 & 100 \\
\hline \multicolumn{5}{|l|}{ UroVysion FISH } \\
\hline \multicolumn{5}{|l|}{ Polysomy } \\
\hline Negative & 35 & 97.2 & 4 & 9.1 \\
\hline Positive & 1 & 2.8 & 40 & 90.9 \\
\hline \multicolumn{5}{|l|}{ p16 deletion } \\
\hline Negative & 31 & 91.2 & 24 & 54.5 \\
\hline Positive & 3 & 8.8 & 20 & 45.5 \\
\hline \multicolumn{5}{|l|}{ STK15 FISH } \\
\hline No amplification & 34 & 94.4 & 0 & 0 \\
\hline Low level amplification & 2 & 5.6 & 28 & 63.6 \\
\hline Amplification & 0 & 0 & 16 & 36.4 \\
\hline
\end{tabular}

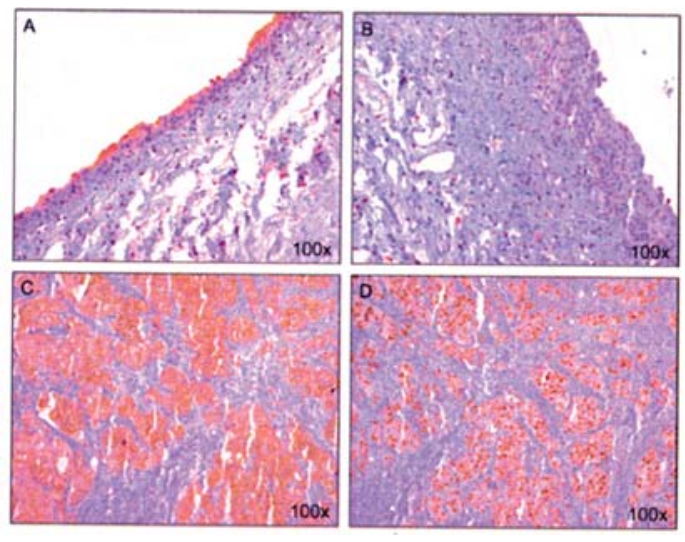

Figure 1. Immunohistochemical staining of histologically benign urothelium and invasive urothelial bladder cancer in the cystectomy tissue microarrayrepresentative examples. Histologically benign urothelium with normal CK20 staining pattern (A) and negative TP53 immunoreactivity (B). Invasive highgrade urothelial bladder cancer with abnormal CK20 staining pattern (C) and positive TP53 immunoreactivity (D).

a bladder cancer nucleus with a star-shaped atypical mitosis and six red STK15 gene signals. In 2 of 36 (5.6\%) histologically benign urothelium samples, low level STK15 amplification was found. Low level STK15 amplification was detected in $64 \%(28 / 44)$ of bladder cancers, whereas $36 \%(16 / 44)$ of cancer lesions demonstrated a high level amplification of the STK15 gene. Results of FISH analysis are summarized in Table II. Descriptive data analysis

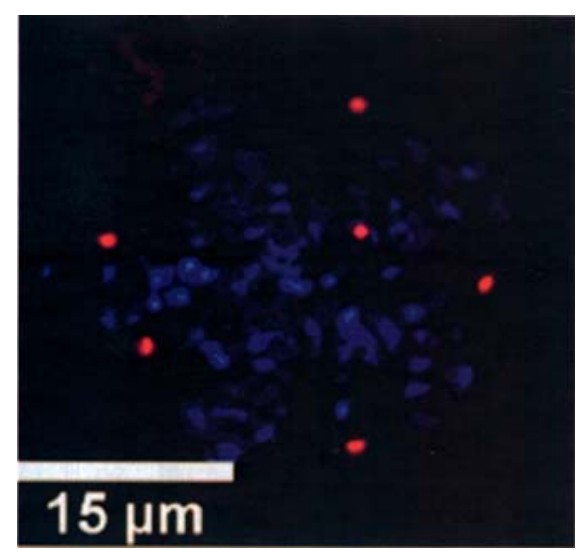

Figure 2. Example of STK15 FISH analysis. A bladder cancer nucleus with a star-shaped atypical mitosis and six red STK15 gene signals (DAPI nuclear counterstaining).

comparing all relevant variables with STK15 amplification status in tumor tissue failed to show significant associations (Table III).

Prognostic relevance. Tumor-specific and recurrence-free survival was compared between cases with and without STK15 amplification by univariate log-rank statistics. Low level STK15 amplification in histologically benign urothelium of patients with urothelial bladder cancer was associated with shorter tumor-specific survival (Fig. 3A). 
Table III. STK15 FISH analysis in urothelial bladder cancer in relation to clinicopathologic, immunohistochemical and FISH data.

\begin{tabular}{|c|c|c|c|c|}
\hline \multirow[b]{2}{*}{ Variable } & \multicolumn{4}{|c|}{ STK15 FISH analysis } \\
\hline & $\mathrm{n}$ analyzable & Low level amplification & Amplification & $\mathrm{P}$-value \\
\hline \multicolumn{5}{|c|}{$\begin{array}{l}\text { Age when cystectomy was } \\
\text { performed (median, range) }\end{array}$} \\
\hline$\leq 70$ years & 24 & 17 & 7 & 0.352 \\
\hline$>70$ years & 20 & 11 & 9 & \\
\hline \multicolumn{5}{|l|}{ Gender } \\
\hline Female & 14 & 7 & 7 & 0.313 \\
\hline Male & 30 & 21 & 9 & \\
\hline \multicolumn{5}{|l|}{ Tumor stage } \\
\hline pT1 & 12 & 9 & 3 & 0.579 \\
\hline pT2 & 13 & 9 & 4 & \\
\hline pT3 & 14 & 7 & 7 & \\
\hline pT4 & 5 & 3 & 2 & \\
\hline \multicolumn{5}{|l|}{ Histologic grade } \\
\hline Low grade & 3 & 3 & 0 & 0.290 \\
\hline High grade & 41 & 25 & 16 & \\
\hline \multicolumn{5}{|l|}{ Lymph node status } \\
\hline pNO & 34 & 20 & 12 & 1.000 \\
\hline $\mathrm{pN} 1$ & 10 & 3 & 2 & \\
\hline \multicolumn{5}{|c|}{ Adjacent carcinoma in situ } \\
\hline No pTis & 18 & 10 & 8 & 1.000 \\
\hline pTis & 26 & 18 & 8 & \\
\hline \multicolumn{5}{|l|}{ Multifocality } \\
\hline Unifocal tumor & 12 & 9 & 3 & 0.487 \\
\hline Multifocal tumor & 32 & 19 & 13 & \\
\hline \multicolumn{5}{|l|}{ Growth pattern } \\
\hline Papillary & 8 & 6 & 2 & 0.153 \\
\hline Solid & 22 & 16 & 6 & \\
\hline Mixed & 14 & 6 & 8 & \\
\hline \multicolumn{5}{|c|}{ Immunohistochemistry (IHC) } \\
\hline \multicolumn{5}{|l|}{ TP53 IHC } \\
\hline$<10 \%$ & 23 & 14 & 8 & 1.000 \\
\hline$\geq 10 \%$ & 21 & 13 & 8 & \\
\hline \multicolumn{5}{|l|}{ UroVysion FISH } \\
\hline \multicolumn{5}{|l|}{ Polysomy } \\
\hline Negative & 4 & 4 & 0 & 0.280 \\
\hline Positive & 40 & 24 & 16 & \\
\hline \multicolumn{5}{|l|}{ p16 deletion } \\
\hline Negative & 24 & 16 & 8 & 0.757 \\
\hline Positive & 20 & 12 & 8 & \\
\hline
\end{tabular}

${ }^{a}$ Fisher's exact test, two-sided.

Patients with low level STK15 amplification in histologically benign urothelium had an estimated mean tumor-specific survival of nine months (95\% confidence interval 3-15) compared to 99 months (95\% confidence interval 84-113) in cases without STK15 amplification. STK15 amplification status in histologically benign urothelium of patients with urothelial bladder cancer was also associated with shorter recurrence-free survival (Fig. 3B). In contrast, there was no 

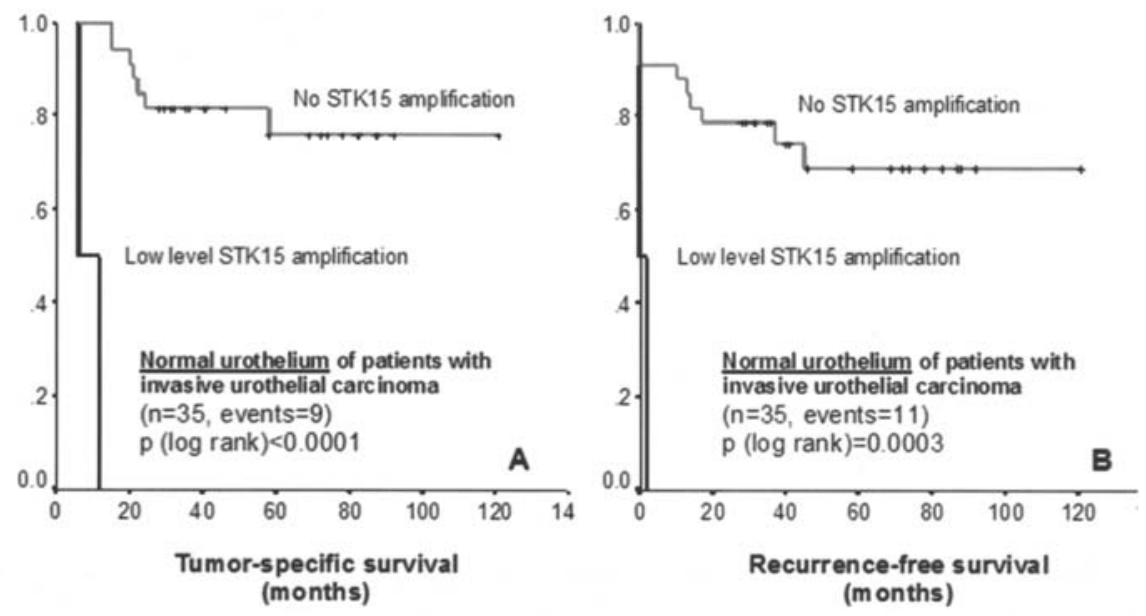

Figure 3. Distributions of time (months) to tumor-related death (A) and tumor recurrence (B) among 35 bladder cancer patients following cystectomy relative to STK15 gene amplification in histologically benign urothelium adjacent to the tumor, as estimated by the method of Kaplan Meier.

Table IV. Tumor-related death and tumor recurrence.

A. Univariate analysis of factors regarding tumor-related death and tumor recurrence in patients with invasive urothelial bladder cancer treated with cystectomy

Tumor-related death

\begin{tabular}{|c|c|c|c|c|c|c|}
\hline \multirow{2}{*}{ Variable } & & \\
\hline & $\mathrm{n}$ & Events & P-value ${ }^{a}$ & $\mathrm{n}$ & Events & P-value ${ }^{a}$ \\
\hline \multicolumn{7}{|c|}{$\begin{array}{l}\text { Age when cystectom } \\
\text { was performed }\end{array}$} \\
\hline$\leq 70$ years & 24 & 4 & 0.0270 & 23 & 6 & 0.1087 \\
\hline$>70$ years & 20 & 9 & & 20 & 9 & \\
\hline \multicolumn{7}{|l|}{ Gender } \\
\hline Female & 14 & 6 & 0.1039 & 30 & 10 & 0.5413 \\
\hline Male & 30 & 7 & & 13 & 5 & \\
\hline \multicolumn{7}{|l|}{ Tumor stage } \\
\hline pT1-2 & 25 & 3 & 0.0020 & 25 & 4 & 0.0017 \\
\hline pT3-4 & 19 & 10 & & 18 & 11 & \\
\hline \multicolumn{7}{|l|}{ Histologic grade } \\
\hline Low grade & 3 & 0 & 0.2776 & 3 & 0 & 0.2216 \\
\hline High grade & 40 & 13 & & 40 & 15 & \\
\hline \multicolumn{7}{|l|}{ Lymph node status } \\
\hline $\mathrm{pNO}$ & 34 & 8 & 0.0253 & 32 & 10 & 0.0635 \\
\hline $\mathrm{pN} 1$ & 10 & 3 & & 5 & 3 & \\
\hline \multicolumn{7}{|l|}{ Residual tumor status } \\
\hline R0 & 36 & 11 & 0.9789 & 32 & 11 & 0.4662 \\
\hline R1 & 8 & 2 & & 6 & 3 & \\
\hline \multicolumn{7}{|c|}{ Adjacent carcinoma in situ } \\
\hline No pTis & 18 & 8 & 0.2166 & 18 & 8 & 0.4814 \\
\hline pTis & 26 & 5 & & 25 & 7 & \\
\hline \multicolumn{7}{|l|}{ Multifocality } \\
\hline Unifocal tumor & 12 & 4 & 0.7360 & 12 & 6 & 0.1950 \\
\hline Multifocal tumor & 32 & 9 & & 31 & 9 & \\
\hline \multicolumn{7}{|l|}{ Growth pattern } \\
\hline Papillary & 8 & 2 & 0.4541 & 8 & 3 & 0.3688 \\
\hline Solid & 21 & 8 & & 21 & 9 & \\
\hline Mixed & 14 & 3 & & 14 & 3 & \\
\hline
\end{tabular}


Table IV. Continued.

B. Univariate analysis of factors regarding tumor-related death and tumor recurrence in tumor tissue Tumor-related death

Tumor recurrence

\begin{tabular}{|c|c|c|c|c|c|c|}
\hline \multirow[b]{2}{*}{ Variable } & & \\
\hline & $\mathrm{n}$ & Events & P-value ${ }^{a}$ & $\mathrm{n}$ & Events & P-value ${ }^{a}$ \\
\hline \multicolumn{7}{|c|}{ Invasive urothelial bladder cancer } \\
\hline \multicolumn{7}{|c|}{ Immunohistochemistry (IHC) } \\
\hline \multicolumn{7}{|c|}{ TP53 IHC } \\
\hline$<10 \%$ & 21 & 3 & 0.0418 & 21 & 5 & 0.1460 \\
\hline$\geq 10 \%$ & 21 & 9 & & 21 & 9 & \\
\hline \multicolumn{7}{|l|}{ UroVysion FISH } \\
\hline \multicolumn{7}{|l|}{ Polysomy } \\
\hline Negative & 4 & 2 & 0.4680 & 4 & 3 & 0.1013 \\
\hline Positive & 39 & 11 & & 39 & 12 & \\
\hline \multicolumn{7}{|l|}{ p16 deletion } \\
\hline Negative & 23 & 6 & 0.6112 & 23 & 6 & 0.2297 \\
\hline Positive & 20 & 7 & & 20 & 9 & \\
\hline \multicolumn{7}{|l|}{ STK15 FISH } \\
\hline Low level amplification & 27 & 7 & 0.5295 & 27 & 9 & 0.9160 \\
\hline Amplification & 16 & 6 & & 16 & 6 & \\
\hline
\end{tabular}

C. Univariate analysis of factors regarding tumor-related death and tumor recurrence in normal urothelium Tumor-related death

Tumor recurrence

\begin{tabular}{|c|c|c|c|c|c|c|}
\hline \multirow{2}{*}{ Variable } & & & & \\
\hline & $\mathrm{n}$ & Events & P-value ${ }^{a}$ & $\mathrm{n}$ & Events & P-value \\
\hline \multirow{2}{*}{\multicolumn{7}{|c|}{$\begin{array}{l}\text { Adjacent normal urothelium } \\
\text { Immunohistochemistry (IHC) }\end{array}$}} \\
\hline & & & & & & \\
\hline \multicolumn{7}{|l|}{ Ki-67 labeling index } \\
\hline$<10 \%$ & 25 & 6 & 0.8143 & 25 & 7 & 0.2459 \\
\hline$\geq 10 \%$ & 11 & 3 & & 11 & 5 & \\
\hline \multicolumn{7}{|l|}{ TP53 IHC } \\
\hline$<10 \%$ & 33 & 8 & 0.9073 & 33 & 10 & 0.4236 \\
\hline$\geq 10 \%$ & 4 & 1 & & 4 & 2 & \\
\hline \multicolumn{7}{|l|}{ CK20 IHC } \\
\hline Superficial staining pattern & 25 & 8 & 0.2799 & 25 & 11 & 0.1242 \\
\hline Negative or $\geq 10 \%$ & 8 & 1 & & 8 & 1 & \\
\hline \multicolumn{7}{|l|}{ UroVysion FISH } \\
\hline \multicolumn{7}{|l|}{ Polysomy } \\
\hline Negative & 34 & 9 & 0.5621 & 34 & 11 & 0.3135 \\
\hline Positive & 1 & 0 & & 1 & 1 & \\
\hline \multicolumn{7}{|l|}{ p16 deletion } \\
\hline Negative & 30 & 8 & 0.9050 & 30 & 10 & 0.9962 \\
\hline Positive & 3 & 1 & & 3 & 1 & \\
\hline \multicolumn{7}{|l|}{ STK15 FISH } \\
\hline No amplification & 33 & 7 & $<0.0001$ & 33 & 9 & 0.0003 \\
\hline Low level amplification & 2 & 2 & & 2 & 2 & \\
\hline
\end{tabular}

${ }^{a}$ Log-rank test, two-sided; bold face represents significant data.

difference in recurrence-free or overall survival in patients with low-level or high-level STK15 amplification in the tumor. Age at diagnosis $>70$ years, initial tumor stage pT3, positive lymph node status and positive TP53 immuno-reactivity in the tumor were significantly associated with shorter tumorspecific survival. None of the other clinicopathologic, genetic or immunohistochemical factors correlated significantly with tumor-specific survival (Table IV). Only tumor stage 
Table V. Multivariate analysis of factors possibly influencing tumor recurrence $(\mathrm{n}=35)$.

\begin{tabular}{|c|c|c|c|c|}
\hline \multirow[b]{2}{*}{ Variable } & \multirow[b]{2}{*}{ Categorization } & \multicolumn{3}{|c|}{ Stepwise reverse selection } \\
\hline & & Hazard ratio & $95 \% \mathrm{CI}$ & P-value \\
\hline \multicolumn{5}{|c|}{ Tumor stage } \\
\hline 0 & pT1-2 & 4.255 & $1.059-17.089$ & 0.041 \\
\hline 1 & pT3-4 & & & \\
\hline \multicolumn{5}{|c|}{$\begin{array}{l}\text { STK } 15 \text { FISH in } \\
\text { normal urothelium }\end{array}$} \\
\hline 0 & No amplification & 6.266 & $0.990-39.668$ & 0.051 \\
\hline 1 & Low level amplification & & & \\
\hline
\end{tabular}

Table VI. STK15 SNP analysis in relation to STK15 gene amplification in urothelial bladder cancers and adjacent normal urothelium.

\begin{tabular}{|c|c|c|c|c|c|}
\hline \multirow[b]{2}{*}{ Variable } & \multicolumn{5}{|c|}{ STK15 SNP analysis } \\
\hline & $\mathrm{n}$ analyzable & $\begin{array}{l}\text { Homozygous } \\
(\mathrm{T} / \mathrm{T})\end{array}$ & $\begin{array}{c}\text { Heterozygous } \\
(\mathrm{A} / \mathrm{T})\end{array}$ & $\begin{array}{l}\text { Homozygous } \\
(\mathrm{A} / \mathrm{A})\end{array}$ & P-value ${ }^{a}$ \\
\hline \multicolumn{6}{|c|}{$\begin{array}{l}\text { Invasive urothelial bladder cancer } \\
\text { STK15 FISH }\end{array}$} \\
\hline Low level amplification & 26 & 18 & 7 & 1 & 0.248 \\
\hline Amplification & 16 & 8 & 8 & 0 & \\
\hline \multicolumn{6}{|l|}{$\begin{array}{l}\text { Adjacent normal urothelium } \\
\text { STK15 FISH }\end{array}$} \\
\hline No amplification & 33 & 23 & 9 & 1 & 0.150 \\
\hline Low level amplification & 2 & 0 & 2 & 0 & \\
\hline
\end{tabular}

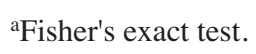

$\geq$ pT3 and low level STK15 amplification in histologically benign urothelium were significantly associated with recurrence-free survival.

Multivariate analyses utilized a Cox proportional hazards model to assess recurrence-free survival rate relative to tumor stage and STK15 amplification in histologically benign urothelium (Table V). As expected, higher tumor stages were significantly correlated with shorter recurrencefree survival. The probability of tumor recurrence was four times higher in post-cystectomy patients with stage pT3 or pT4 bladder cancer than that in patients with stage pT1 or pT2 cancers. Low level STK15 amplification in histologically benign urothelium showed a trend towards significance regarding tumor recurrence in our small patient cohort $(n=35)$.

SNP analysis. The STK15 T91A polymorphism analysis was informative in 42/44 cases (DNA from two cases showed no amplification products). Polymorphic alleles segregated as
TT (62\%), AT (36\%), and AA (2\%). This allelic distribution was compared to large case-control studies in healthy Caucasians (11), which showed polymorphism frequencies similar to those in our series. There was no correlation between allelic variants and high/low level of STK15 gene amplification (Table VI).

\section{Discussion}

One significant risk factor in bladder cancer is DNA aneuploidy of tumor cells. Patients with aneuploid pTa and pT1 urothelial tumors had a higher rate of recurrence and poor clinical outcome (15). Invasive tumors frequently display widespread chromosome aneuploidy and extensive genetic alterations, e.g. defective TP53 and chromosome 20q amplifications $(16,17)$. Amplification of chromosome $20 \mathrm{q}$ may be a critical step in tumorigenesis since it is associated with invasion in urothelial cancers, squamous cell carcinoma of the cervix, and breast cancer $(18,19)$. Recently, several 
studies analyzed the role of STK15 within chromosome $20 \mathrm{q}$ in urothelial bladder cancer. Overexpression of STK15 showed a strong correlation with stage and grade of $\mathrm{pTa} /$ pT1 tumors and was an independent predictor of tumor recurrence (7).

This study shows low level STK15 amplification in $5.6 \%$ of histologically benign urothelium of bladder cancer patients. Most associated tumors were classified as stage pT3G3 urothelial bladder cancers with solid growth pattern and TP53 overexpression. One cancer was multifocal with adjacent carcinoma in situ (pTis), and another was node positive ( $\mathrm{pN} 1)$ with solitary growth pattern. Most striking is that low level STK15 amplification in histologically benign urothelium of bladder cancer patients was associated with shorter recurrence-free and tumor-specific survival following cystectomy. Functional studies revealed STK15 as a key regulatory component of the TP53 pathway, and overexpression of STK15 leads to increased degradation of TP53, which in turn causes downregulation of checkpointresponse pathways and facilitating oncogenic transformation of cells (20). In vitro studies showed enhanced chromosomal instability in bladder cancer cell lines overexpressing STK15 (9). Fraizer et al suggested that overexpression of STK15 in bladder tumor cells contributes to tumor progression by promoting chromosomal instability and subsequent aneuploidy (9). STK15 gene amplification and protein expression have been linked to aneuploidy of bladder cancer and clinical tumor aggressiveness. Tumors with low level STK15 amplification (3-4 copies) showed minimal deviation in their chromosome copy number and diploid or neardiploid total nuclear DNA content. Tumors with higher levels of STK15 amplification ( $>4$ copies) had a major increase in both chromosome copy number and total nuclear DNA content; i.e. exhibited pronounced aneuploidy. Overexpression of STK15 was strongly associated with high histologic grade, invasion, increased rate of metastasis, and decreased metastasis-free and overall survival of patients (8). No significant association with TP53 expression, p16 deletions or polysomy was found in our study (Table III).

The primary indication for cystectomy is muscle-invasive bladder cancer. Other relative indications are high-risk urothelial neoplasia (pT1 high-grade, BCG-resistant pTis), and extensive non-invasive papillary bladder tumor disease (pTa high-grade) that cannot be controlled through conservative measures. Management of stage pT1G3 bladder cancer is still controversial (21), and it is far from certain whether TP53 status can help to select pT1 tumor patients who may benefit from early cystectomy. Recent studies on FGFR3 and TP53 mutations failed to predict, alone or in combination, recurrence or survival of pT1G3 tumor patients $(22,23)$. In our study, TP53 expression $(\geq 10 \%)$ was associated with shorter tumor-related survival (Table IV, B).

The allelic distribution of the functional Phe31Ile polymorphism of STK15 affected cancer risk in several tumor types (11), and most studies found the homozygous 31Ile variant to associate with aggressive and invasive tumors. Our own analysis suggests no association of the Phe31Ile polymorphism with cancer risk or tumor ploidy in this limited sample. The STK15 Phe31Ile polymorphism may not play a role in tumors of the genitourinary tract, similar to data obtained from renal cell carcinomas (24). Gu et al found a reduction of lung cancer risk of the homozygous 31Ile variant in Caucasians (25), underscoring a probably complex and cancer-type specific modification of cancer risk by STK15 variants. More studies are needed to clarify the role(s) of functional STK15 variants.

Applying STK15 FISH to benign urothelium of bladder cancer patients may help to identify patients at increased risk for adverse clinical outcome. A large randomized prospective study comparing early versus delayed cystectomy in patients with pT1 bladder cancer is currently conducted to validate our findings.

\section{Acknowledgements}

We thank Rudolf Jung, Nina Niessl, and Monika Kerscher for excellent technical assistance. This study was supported by a grant from the German Reseach Foundation (DFG) to R.K. (Knü 263/9-2). Data were presented in part at the 88th Annual Meeting of the German Society of Pathology, June, 2004, Rostock, Germany.

\section{References}

1. Lengauer C, Kinzler KW and Vogelstein B: Genetic instability in colorectal cancers. Nature 386: 623-627, 1997.

2. Sen S: Aneuploidy and cancer. Curr Opin Oncol 12: 82-88, 2000.

3. Cahill DP, Kinzler KW, Vogelstein B and Lengauer C: Genetic instability and darwinian selection in tumours. Trends Cell Biol 9: 57-60, 1999.

4. Zhou H, Kuang J, Zhong L, et al: Tumour amplified kinase STK15/BTAK induces centrosome amplification, aneuploidy and transformation. Nat Genet 20: 189-193, 1998.

5. Miyoshi Y, Iwao K, Egawa $C$ and Noguchi S: Association of centrosomal kinase STK15/BTAK mRNA expression with chromosomal instability in human breast cancers. Int J Cancer 92: 370-373, 2001.

6. Grady WM: Genomic instability and colon cancer. Cancer Metastasis Rev 23: 11-27, 2004.

7. Mhawech-Fauceglia P, Fischer G, Beck A, Cheney RT and Herrmann FR: Raf1, Aurora-A/STK15 and E-cadherin biomarkers expression in patients with $\mathrm{pTa} / \mathrm{pT} 1$ urothelial bladder carcinoma; a retrospective TMA study of 246 patients with long-term follow-up. Eur J Surg Oncol 32: 439-444, 2006.

8. Sen S, Zhou H, Zhang RD, et al: Amplification/overexpression of a mitotic kinase gene in human bladder cancer. J Natl Cancer Inst 94: 1320-1329, 2002.

9. Fraizer GC, Diaz MF, Lee IL, Grossman HB and Sen S: Aurora-A/STK15/BTAK enhances chromosomal instability in bladder cancer cells. Int J Oncol 25: 1631-1639, 2004.

10. Ewart-Toland A, Briassouli P, De Koning JP, et al: Identification of Stk6/STK15 as a candidate low-penetrance tumorsusceptibility gene in mouse and human. Nat Genet 34: 403-412, 2003.

11. Ewart-Toland A, Dai Q, Gao YT, Nagase H, et al: Aurora-A/ STK15 T+91A is a general low penetrance cancer susceptibility gene: a meta-analysis of multiple cancer types. Carcinogenesis 26: $1368-1373,2005$.

12. Simon R, Atefy R, Wagner U, et al: HER-2 and TOP2A coamplification in urinary bladder cancer. Int J Cancer 107: 764-772, 2003.

13. Eble JN, Sauter G, Epstein JI and Sesterhenn I: Pathology and genetics of tumours of the urinary system and male genital organs. In: World Health Organization Classification of Tumours. Eble JN (ed.). IARC Press, Lyon, pp143-145, 2004.

14. Harnden P, Mahmood N and Southgate J: Expression of cytokeratin 20 redefines urothelial papillomas of the bladder. Lancet 353: 974-977, 1999.

15. De Vere White RW, Deitch AD, Tesluk H, et al: Prognostic significance of DNA ploidy in Ta/T1 bladder cancer: a SouthWest Oncology Group Study. Urol Oncol 2: 27-34, 1996. 
16. Richter J, Beffa L, Wagner U, et al: Patterns of chromosomal imbalances in advanced urinary bladder cancer detected by comparative genomic hybridization. Am J Pathol 153: 1615-1621, 1998.

17. Richter J, Wagner U, Schraml P, et al: Chromosomal imbalances are associated with a high risk of progression in early invasive (pT1) urinary bladder cancer. Cancer Res 59: 5687-5691, 1999 .

18. Wilting SM, Snijders PJ, Meijer GA, et al: Increased gene copy numbers at chromosome $20 \mathrm{q}$ are frequent in both squamous cell carcinomas and adenocarcinomas of the cervix. J Pathol 209: 220-230, 2006.

19. Nessling M, Richter K, Schwaenen C, et al: Candidate genes in breast cancer revealed by microarray-based comparative genomic hybridization of archived tissue. Cancer Res 65: 439-447, 2005.

20. Katayama H, Sasai K, Kawai H, et al: Phosphorylation by aurora kinase A induces Mdm2-mediated destabilization and inhibition of p53. Nat Genet 36: 55-62, 2004.

21. Metwalli AR and Kamat AM: Controversial issues and optimal management of stage T1G3 bladder cancer. Expert Rev Anticancer Ther 6: 1283-1294, 2006.
22. Grossman HB, Tangen CM, Cordon-Cardo C, et al: Evaluation of Ki67, p53 and angiogenesis in patients enrolled in a randomized study of neoadjuvant chemotherapy with or without cystectomy: a Southwest Oncology Group Study. Oncol Rep 16: 807-810, 2006.

23. Hernandez S, Lopez-Knowles E, Lloreta J, et al: FGFR3 and Tp53 mutations in T1G3 transitional bladder carcinomas: independent distribution and lack of association with prognosis. Clin Cancer Res 11: 5444-5450, 2005.

24. Hammerschmied CG, Stoehr R, Walter B, Wieland WF, Hartmann A, Blaszyk H and Denzinger S: Role of STK15 Phe31Ile polymorphism in renal cell carcinoma. Oncol Rep 17: 3-7, 2007.

25. Gu J, Gong Y, Huang M, Lu C, Spitz MR and Wu X: Polymorphisms of STK15 (Aurora-A) gene and lung cancer risk in Caucasians. Carcinogenesis, August 21, Epup, doi:10.1093/ carcin/bgl149. 